\title{
PLACES OF MEMORY: HOLOCAUST MEMORIALS IN VIDZEME AND THEIR SYMBOLIC LANGUAGE
}

\author{
Solveiga Krümiņa-Koņkova \\ A leading researcher at the Institute of Philosophy and Sociology, University of \\ Latvia \\ e-mail: solveiga.krumina-konkova@lu.lv
}

\begin{abstract}
In analysing the symbolic language of Holocaust memorials, the author uses the concept of lieux de mémoire, elaborated by the French historian Pierre Nora. Nora highlights the essential differences, even rupture, between history and memory and the growing importance of lieux de mémoire, places of memory that lie between memory and history. The task of these places is to return the event to the present, reviving it in both the individual memory and the memory of society. Therefore, a memorial can also be considered a lieu de memoire. Moreover, the memorial is a more complicated case with material, symbolic and functional significance, a lieu de mémoire and a historical text with changing relations between them.

The paper will briefly describe the basic principles of Holocaust iconography and the history of the development of Holocaust memorials as a new genre of commemorative art. The author will look at the development of this genre in Latvia using the example of memorials dedicated to victims of Nazism in Vidzeme. The monument's symbolic language and whether it has been influenced by the specific place and events or whether artists have followed a specific iconographic canon will be explained. The examples will also be considered from the point of view of the dialectics between a place of memory and a historical text, mentioned above.
\end{abstract}

Keywords: Holocaust memorial, Pierre Nora, lieux de mémoire, Harold Marcuse, Holocaust iconography 


\section{Introduction}

Among the dark legacies of the twentieth century that have an important place in the cultural memory of European and Latvian society is the Holocaust. The American historian Dominick LaCapra, best known for his work in European intellectual history and trauma studies, has very precisely pointed out the essence of the Holocaust as 'a complex phenomenon at the intersection of history and memory with which we are still trying to grapple' (LaCapra 1998: 1). As elsewhere globally, dozens of memorials in Latvia also mark sites of the Nazi persecution and the mass murder of the Jews. 'The design and content of Holocaust memorials reflect national differences in historiography, ideology and culture as well as a variety of styles and traditions of public art and sculpture. Many sites reflect local events or specific aspects of the Holocaust' (Milton 1991: 9). Such memorials might be the most significant movement in the remembrance of the Holocaust. There are several reasons for this. Memorials are primarily located in the places where the events of the Holocaust took place. Therefore, on the one hand, to create a monument, the artist needs the local community's involvement. On the other hand, the memorial's message not to forget past events and their victims in this community is unambiguous. 'Despite the specificity of each site and despite national differences in perspective and emphasis, these memorials collectively preserve for posterity the public memory of Nazi mass murder' (Milton ibid.).

In analysing the symbolic language of Holocaust memorials, the author of this paper will use the concept of lieux de mémoire, elaborated by the French historian Pierre Nora. According to Nora, lieux de mémoire are places where 'memory is crystallised, in which it finds refuge' (Nora 1997: 1). Nora emphasised that in these places, a 'residual sense of continuity remains', and what is even more important - these places 'exist because there are no longer any milieux de mémoire, settings in which memory is a real part of everyday experience' (ibid.).

For Nora, in many respects memory and history are opposites. If memory is life, if it is remembering and forgetting, if it can sleep for years, only to wake up suddenly with new power, then history is only a reconstruction, always problematic and unfinished, because it tries to reconstruct what is and will remain the past. Showing the irreconcilability of these opposites, Nora admits that 'society living wholly under the sign of history would not need to attach 
its memory to specific sites any more than traditional societies do' (Nora 1997: 3). However, we should agree with LaCapra when he points out that 'Nora feels that something essential has been lost, and - whether or not the loss is itself imaginary - the very opposition between history and memory serves to commemorate and assuage it' (LaCapra 1998: 19). Lieux de mémoire have a growing importance in these problematic relationships between memory and history because they lie between them. They do not allow an event to become just a thing of the past. The task of these places is to return the event to the present and revive it in the individual memory and the memory of society as well.

Nora stresses that memory situates remembrance in a sacred context (Nora 1997: 3). Mention may also be made here of the Jewish historian and essayist Saul Friedlander's argument that memory 'reinterpreting the past through representation allows one to see hidden forms and new levels of discourse, and to try to exorcise the evil of this past' (Friedlander 1993: 18). Also, according to LaCapra, the memory may be informative 'not in terms of an accurate empirical representation of its object but in terms of that object's often anxiety-ridden reception and assimilation by both participants in events and those born later' (LaCapra 1998: 19). However, being phenomena of emotions, memory and remembrance are fragile, especially because memories of the tragic call for silence: 'Silence itself is more accurate or truthful or morally responsive' than testimonies of history (Lang 2000: 9).

Nevertheless, silence also limits the representation of the past event and can turn this event into absence. We see so many memorial places overgrown in the grass, and we can no longer say anything about them and the events about whom they have ever told! 'Absence' may indeed be gradually becoming 'a word associated with memory which is largely a negative form of memory' (Feinstein 2005: xxii). It is a memory that has ceased to be present at all.

For the event to be an event again, it must be known. When memories become absent, when no one remembers them, they can only be reborn by history. Therefore, history can be viewed as the transmission of critically tested memories. That does not involve a direct survival of the 'true memory ' but is a cultural product compensating for the absence of memory. The new memory is memory integrated into history. LaCapra finds that history is its 'own variant of the form of memory work and working - through that is embodied in mourning, a process that may be called for with respect to victims of traumatic 
events' (LaCapra 1998: 20). The Holocaust, which belongs to the dark legacy of humanity, is undoubtedly such an event.

Returning to Nora's lieux de mémoire, it should also be mentioned that the French philosopher Paul Ricoeur characterises such places as 'contemporaneous with memory seized by history and not rebellion with respect to history' (Ricoeur 2009: 403). Ricoeur refers to Nora's conclusion that places of memory are granted remarkable efficiencies, 'the capacity to produce "another history". They draw this power from the fact that they partake of the orders of both memory and history' (ibid.: 405).

From this point of view, memorials also should be lieux de mémoire because they are the 'betweenness ', that is, they are between memory and history. At least we can evaluate memorials according to whether they are only topographical marks of historical places or also lieux de mémoire. However, a memorial as a symbolic object of memory is also an essential instrument of historical work that is not to be forgotten. Even if we recognise one or another memorial as a specific place of memory, we must not forget that each memorial is more complicated because of its material, symbolic and functional significance. 'The first anchors the places of memory in realities that can be said to be already given and manipulable; the second is the work of the imagination, and it assures the crystalising of memories and their transmission; the third leads back to ritual, which history nevertheless attempts to dismiss' (Ricouer 2009: 405). Besides, no matter how contradictory and complicated the relationship between the three parties may be, the importance of memory places lies in representing the 'maximum possible meaning with the fewest possible signs' (ibid.). Therefore, a memorial is at the same time a place of memory and a historical text with a very complex dialectic between them.

\section{Holocaust memorials as a new genre of commemorative art}

According to the American professor of German history, Harold Marcuse, Holocaust memorials are a new genre of commemorative art:

they are addressed to transnational audiences; they often explicitly represent multiple meanings; and they use a new repertoire of symbols, forms, and materials to represent those meanings. By the time they emerged as 
a distinct genre around 1960, Holocaust memorials tended to be complex experiential spaces, usually going beyond mere documentary markers to include significant didactic accoutrements. (Marcuse 2010: 54)

There are several essential highlights in this quote from Marcuse, which should be considered before we take a closer look at the Holocaust memorials in Vidzeme.

First, we can only talk about Holocaust memorials as a specific genre from the 1960s. An American scholar of Nazi Germany and the Holocaust, Sybil Milton, points out that during 1950

the first European memorials fell into one of two broad organisational patterns. In Eastern Europe the memorials were usually seen as forms of symbolic politics under the direction and financial patronage of the central government. In Western Europe the memorials were usually left to private and local initiative and thus developed in an ad hoc and piecemeal fashion. The ambivalences and inadequacies of this initial phase in the institutionalisation of the Holocaust were irreversible and provided the context for all subsequent developments. (Milton 1991: 21)

Holocaust monuments and memorials before that time reflected selected aspects of national style, religious tradition, public expectation and artistic skill. Most of them were derived from either classical funeral monuments (obelisks, tall pylons, stelae in classical geometric forms) or traditional war memorials.

Sometimes, the monuments were used simply to mark a mass murder or a burial site as meaningful but without specifying that meaning. Nevertheless, even simple preservation of these places as such, even without additional monuments, was an act of memorialization (Milton 1991: 16). It turned these places into meaningful and impressive lieux de mémoire, which were at the same time easy-to-understand general historical messages about the tragic events that had taken place in these places, but without specific details.

The early memorials were created using predominantly Christian iconography commemorating heroism and patriotism usually associated with military victories or losses. Therefore, their symbolic language was inappropriate for the victims of the Nazi massacres and significantly changed the emotional background to their places of memory. 
The early memorials were created using predominantly Christian iconography commemorating heroism and patriotism usually associated with military victories or losses. Therefore, their symbolic language was inappropriate for the victims of the Nazi massacres and significantly changed the emotional background to their places of memory.

Furthermore, Milton argues that the linkage of liturgical and didactic elements in most memorials is reflected in an ideologically diversified fashion in various changing national historical memories that are concerned as much with the past as with the present and the future' (Milton 1991: 15). In many cases, the memorials' focus was not the commemoration of the victims but a celebration of the anti-fascist resistance. Marcuse points out that the traditional form of memorial indicates that the survivors had not yet derived a specific meaning from the experience they wish to represent (Marcuse 2010: 58). Simultaneously, as seen in some examples of Soviet-era monuments in Latvia, post-war monuments with their laconic generalizations perfectly correspond to the need to deprive the victims of their individuality. They are all the same and are anonymous. This specific is also indicated by Milton, who that

many European memorials do not mention Jews explicitly, thereby reflecting the ideological views of Communist regimes, which emphasise political resistance: similar approaches in non-Communist countries in the West are not common knowledge. These national memorials are often self-serving, attributing a national identity to the victims not granted to them in their lifetimes. Thus, the posthumous acknowledgement transforms Polish Jews into Poles and French Jews into French. (Milton 1991: 19)

In the socialist countries of the Eastern Bloc, there were also figurative memorials in the style of socialist realism, often depicting groups of people to express international solidarity as a movement. The Jews were only one group among several others. A consideration of both memorials in Eastern and Western Europe indicates that specifically Jewish symbols were problematic in the early memorial iconography. The six-pointed Star of David, a menorah or the fivepointed communist red star were used to specify the categories of victims that were commemorated on the monuments and nothing else. The anonymity and isolation of individuals caught up in the machinery of mass murder tends to be emphasized (Marcuse 2010: 55). The concealing of Jewish victims stands in sharp contrast to American and Israeli memorials, where the reverse exclusion 
applies. According to Milton, this peculiarity developed mainly because the most significant impetus and financing for memorials in those two counties had come from Jewish survivors (Milton 1991: 19). an issue of national identification, touristic attraction and local branding. The discussion brought in some parallels of the transformation in the traditional holiday meals in other European countries, partly because of the trend towards vegetarianism, healthy food, and restrictions on eating bread. It is seen as a conflict between generations, when grandmothers want to make their grandchildren eat traditional "unhealthy" calories - rich food such as pork and bread, and the youngsters protest against it.

The specific Jewish dimension of the Nazi genocide began to emerge in the public sphere in the 1950s. This milestone was primarily because the understanding of the Nazi genocide as a programme distinct from the atrocities committed during World War II began to emerge only in this period.

According to Marcuse, the international competition for a memorial for Auschwitz-Birkenau

marks a transition to a wholly new genre of the memorial: more expansive, complex, mostly abstract, avant-garde sculptures that create or incorporate experiential spaces with multiple symbolic elements. Although "the Holocaust" in its specifically Jewish meaning was not a prominent event of public commemoration also in the 1950s, a symbolic language of specific Holocaust memorials, the iconography and aesthetic traditions of its later representation did emerge during that decade. (Marcuse 2010: 89)

For example, the symbolic meaning was given to materials used for the memorial. There were stones from concentration camp quarries, such as the granite in the Mauthausen memorial in the Pére Lachaise Cemetery in Paris (1958). the marble used in the Jewish memorial at Dachau (1967) came from Peki'in in Israel, which is believed to have had a continuous Jewish settlement since biblical times. Numerous Holocaust memorials incorporate containers of human ash or 'blood-soaked' soil from Nazi concentration camps and sites of mass murder (Marcuse 2010: 56). Religious symbols and references to the ancient history of the Jews as 'witness people myth' (Haynes 1995: 8), the belief that whatever happens to the Jews, for good or evil, is an expression of God's providential justice and, as such, is a sign for 'God's church', are also gaining in importance. 
This newly created symbolic language varies essentially from earlier memorial traditions of war-related mass deaths. Marcuse points out that the need for this new symbolic representation is predicated on the absence of what is symbolised (Marcuse 2010: 58). However, that is just one of the reasons: the use of symbolic language for the message of Holocaust memorials, which is addressed to everyone, is no less important.

In this context, Marcuse's assumption that the establishment of specific Holocaust memorials after the 1960s was very often determined not by the place where they were located nor by events that had happened in this place should be considered. Although the events undoubtedly gave rise to a specific iconography, Marcuse emphasizes the more crucial role of the agents, the groups of initiators behind the memorials and their intended audiences. He admits that 'in fact, some of the core event-sites of the Holocaust, including Babi Yar, Belzec, Chełmno, Sobibor, and Treblinka, were not memorialised at all until the 1960s when agents and audiences emerged who took an interest in transmitting their memory' (Marcuse 2010: 55). That is, these places of memory were not initially chosen due to their links with past events: they became places of memory due to political preferences.

The development of similar processes in Latvia was hindered by the Soviet regime, which found memorials dedicated to the Holocaust unacceptable. They also had no target audience. Specific Holocaust memorials were discovered mainly after the collapse of the Soviet regime at the beginning of our century.

\section{Symbolic language of holocaust memorials in Vidzeme}

Vidzeme, literally meaning 'the Middle Land', is one of Latvia's historical and cultural regions, situated in north-central Latvia, north of the Daugava River. In the southwestern part of Vidzeme is Riga, Latvia's capital. In Vidzeme, outside Riga, 2,500 Jews were registered in 1935 (Bedik̦e 2000), in which year 43,672 Jews also lived in Riga. Most of them were killed in the Holocaust in 1941.

Of the thirty memorials in Vidzeme and eleven in Riga that mark Holocaust-related places, the most typical and the most original memorials will be described in this article.

Many of the memorials that were erected shortly after the war on the sites of the deaths or mass burials have not survived. As elsewhere in Europe and Latvia, these post-war Holocaust memorials primarily served as memorials 
to the dead. According to the information we have, they were mainly simple wooden or, in some cases, stone slabs with laconic inscriptions about the place of the killing or mass burial of victims of fascism or Soviet patriots. Those who put them up were mainly the relatives of those who had been murdered or themselves survivors of the Holocaust. It should be emphasized here that the surviving part of the Jewish population of Latvia 'was not willing to conform to the Soviet narrative which emphasised exclusively "Soviet citizens - victims of the Nazi barbarians". They therefore shaped the alternative memory, or countermemory, to the Soviet vision of the Second World War' (Zisere 2019: 302).

The the Soviet regime silence imposed on the Holocaust means that many sites of mass murder can only be indicated today by coordinates recorded in certain archival documents or books. Still, the sites themselves can no longer be found, and even those living close to them do not know about the terrible events associated with them. It can therefore be said that these places have ceased to be memory places: 'without commemorative vigilance, history has soon swept them away' (Nora 1997: 7).

In some cases, however, the earliest Holocaust memorials have survived both as places of remembrance and as historical text. They are designed as tombstones, thus symbolising the sorrow for the dead. However, the epitaphs on these monuments do not contain more detailed information about those for whom we are asked to mourn. Created according to Soviet guidelines on anonymous Soviet citizens who were victims of the Nazi regime, the epitaphs render this mourning meaningless and turn the memory of them into its absence. One such example is the Smiltene Forest Cemetery memorial, where in 1947 some of the remains of the two hundred Jews killed near Smiltene were reburied (here and below I am relying on data from Melers 2013). The inscription on this memorial states: 'Eternal remembrance to those fallen we build. In joint work for the future, we find strength in remembrance of heroes!' As can be seen from this epitaph, the victims to whom this monument was dedicated are anonymous. Understandably, many of them were unknown, but even when their names were discovered, the policy of anonymity continued, as it does, moreover, even thirty years after the fall of the Soviet regime. 


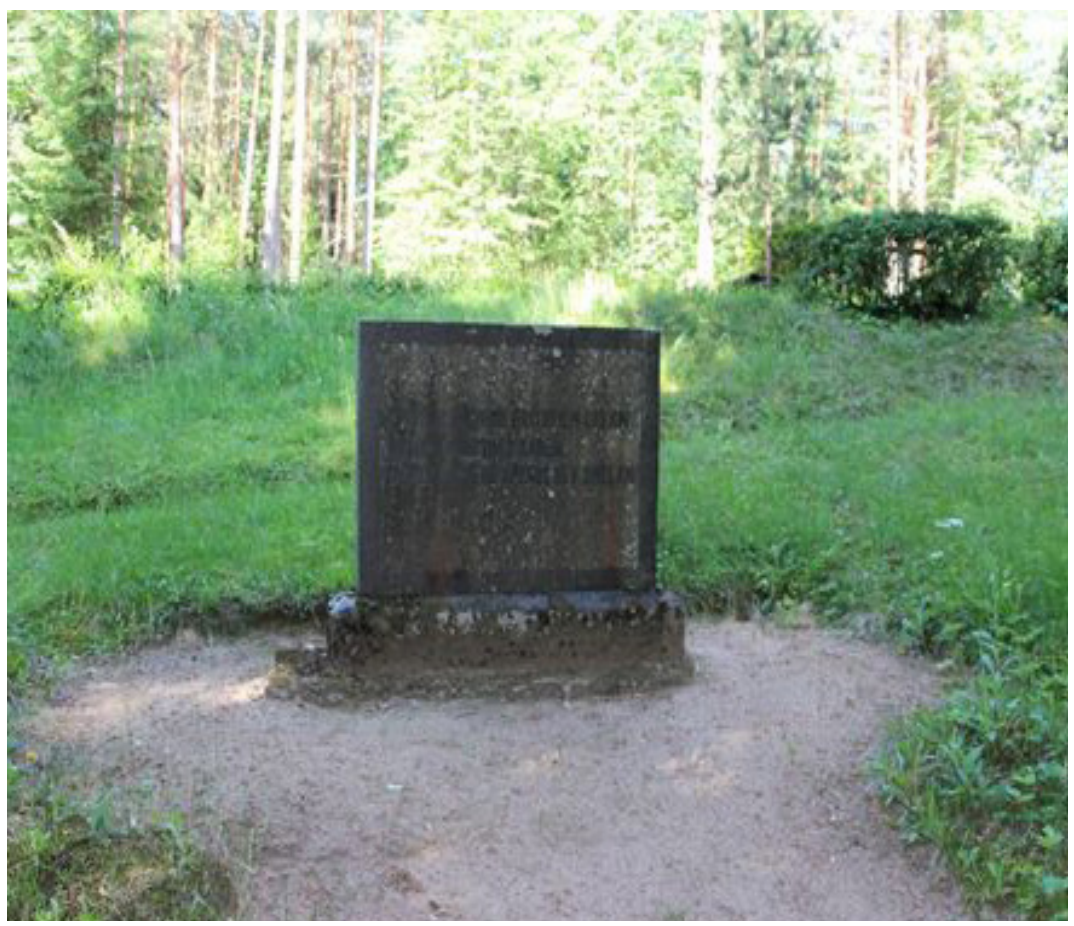

Figure 1. The tombstone in the Smiltene Forest Cemetery. Summer of 2020. Photo by Solveiga Krumina-Konkova

In 1948 a monument was unveiled on the site of the mass murder in Kelderleja near Valmiera. It was dedicated to all the victims who had been killed on this site (approximately three thousand residents of Valmiera). The monument is in the shape of a grey granite stele with an inscription in Latvian 'To Victims of Fascism of 1941' and a poem as at Smiltene.

This monument has not undergone any significant changes since Soviet times, but the impression it makes is different from that made by the Smiltene monument. In Kelderleja, we can talk about complementary relations between this place of memory and the historical text. In this case, the historical text is not just a piece of historiography conveying information about the massacres in Kelderleja in 1941-1942, but also the location of this site itself in a forested 
ravine. For those who know what happened in Kelderleja, the road to the monument itself is also a historical text. It inadvertently allows us to imagine those who were driven to Kelderleja many decades ago and their feelings: ignorance and fear, alternating with a sudden realization of what awaited them deeper in the woods and that there would be no way back. Thus, the path tells us what we could see next. And not even what we will see, but rather feel - a depressing mourning silence. The mood of this place of memory dominates over the anonymising inscription of the monument, essentially abolishing it. Of course, it should be noted here that this place of memory is focused on individual psychology, not on the collective commemoration of the massacre.

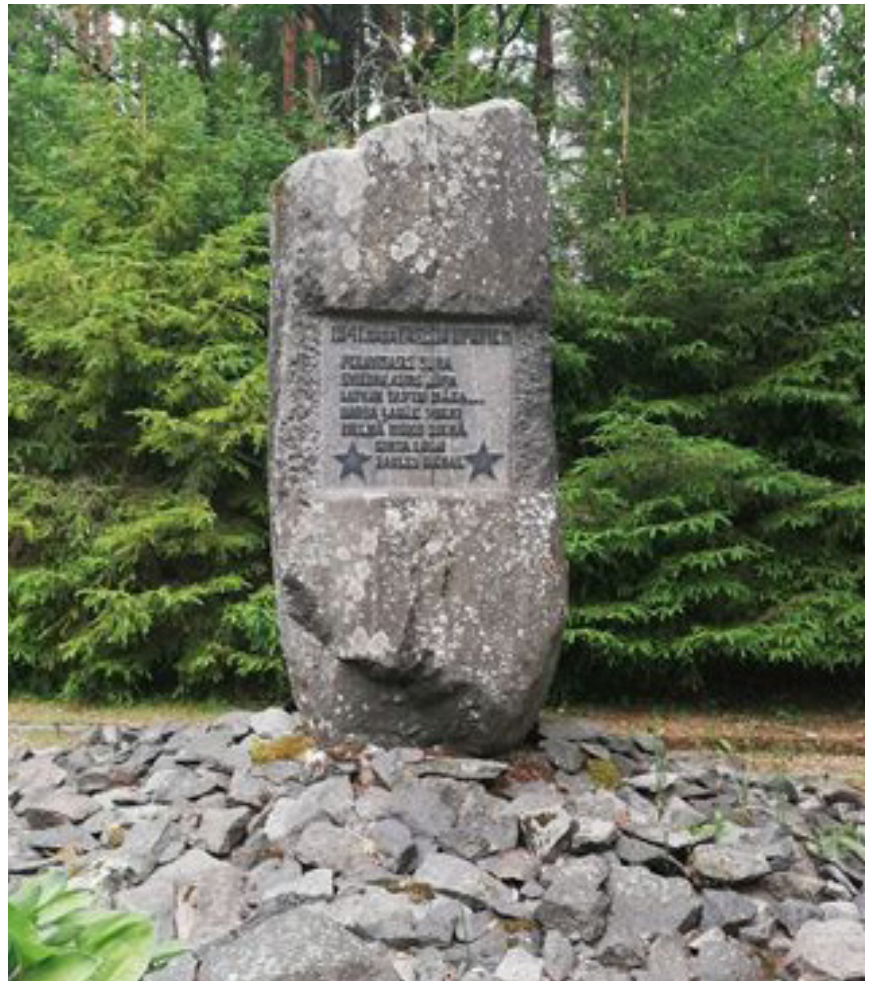

Figure 2. Memorial in Ķelderleja near Valmiera. Summer of 2020. Photo by Solveiga KruminaKonkova 
In these examples, we see a typical feature of Soviet-era commemoration. Except for Riga, there were no Holocaust memorials in Vidzeme during the Soviet period. Most of the memory places were created as memorials to all victims of Nazism without highlighting the Jews. This attitude was justified by arguing that Jews, Roma, Latvians and representatives of other nationalities Soviet activists and prisoners of war - were killed and buried together and were all Soviet citizens. Only by reburying the dead were the Jews, probably at the community's request, buried separately, for example, in Smiltene and Valmiera, which we will talk about next. In the case of Smiltene, it can be said that the inscription on the grave is even misleading because it hides the nationality of those of have been reburied there.

In 1985 the Brethren Cemetery was opened in Valmiera to reinter Soviet soldiers and victims of the Nazi mass murders in Kelderleja. The remains of the Jews were reburied separately, at a place marked by a granite plaque and an apple tree, the latter giving this stie the name 'Golden Apple-tree.' The idea of creating a more monumental memorial site was not realized, and it is now difficult to consider it a place of memory at all: it can only be called a symbol of oblivion. Remembering Nora again: when 'the memorial has swung over into the historical', history begins to write its own history, and memory spaces can easily be reduced (Nora 1974: 212). The Brothers' Cemetery Ensemble is currently being renewed, and it is to be hoped that the Golden Apple-tree Memorial Site will also be restored.

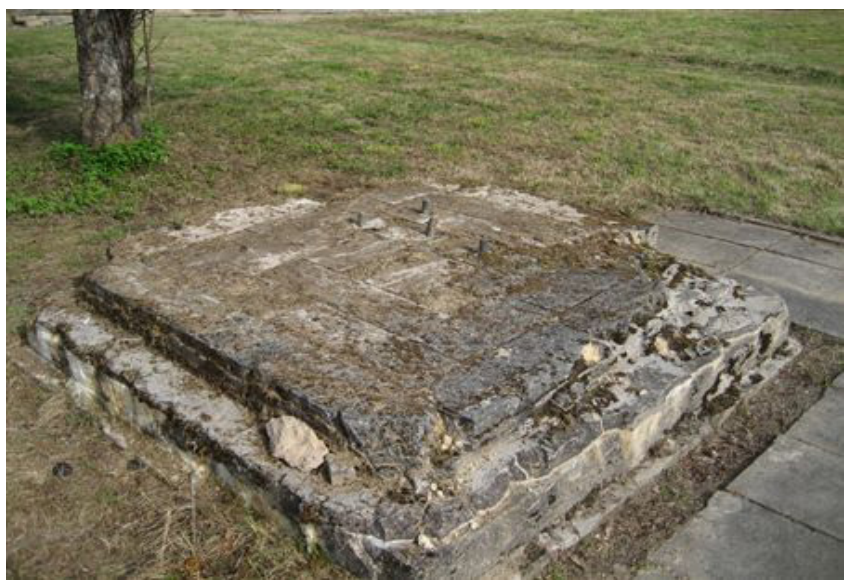

Figure 3. Golden Apple-tree memorial site in Valmiera. Photo From the site: Holocaust Memorial Places in Latvia. (c) 2021 Center for Judaic Studies at the University of Latvia. 
In the 1960s, like elsewhere in Europe, this new genre of memorial began to appear in Latvia: more expansive, more complex and consisting primarily of abstract, avant-garde sculptures that create or incorporate experiential spaces with different symbols.

In 1967, on the site of the Salaspils concentration camp, an impressive monumental memorial was opened, designed by the architects Gunārs Asaris, Ivars Strautmanis, Oḷgerts Ostenbergs and Oḷegs Zakamennijs. The memorial creates a symbol of the border between life and death with a hundred-metrelong concrete wall. The visitors can read the words written on the wall - 'Beyond these gates, the land groans'. Behind the wall is a ceremonial square with a pedestal in black granite designed for laying official wreaths. The artificial heartbeat of the metronome can be heard throughout the memorial. There are also seven concrete sculptures, called respectively 'Mother,' 'The Unbroken', 'The humiliated,' 'Protest,' 'Red Front', 'Solidarity' and 'The Oath. Thus, the ensemble's symbolism was related more to the theme of international solidarity than to compassion for the victims of the Nazi regime. Also, it did not contain any obvious reference to the Holocaust, although this former labour correctional camp was built by Jews from Germany, Austria and Czechoslovakia.

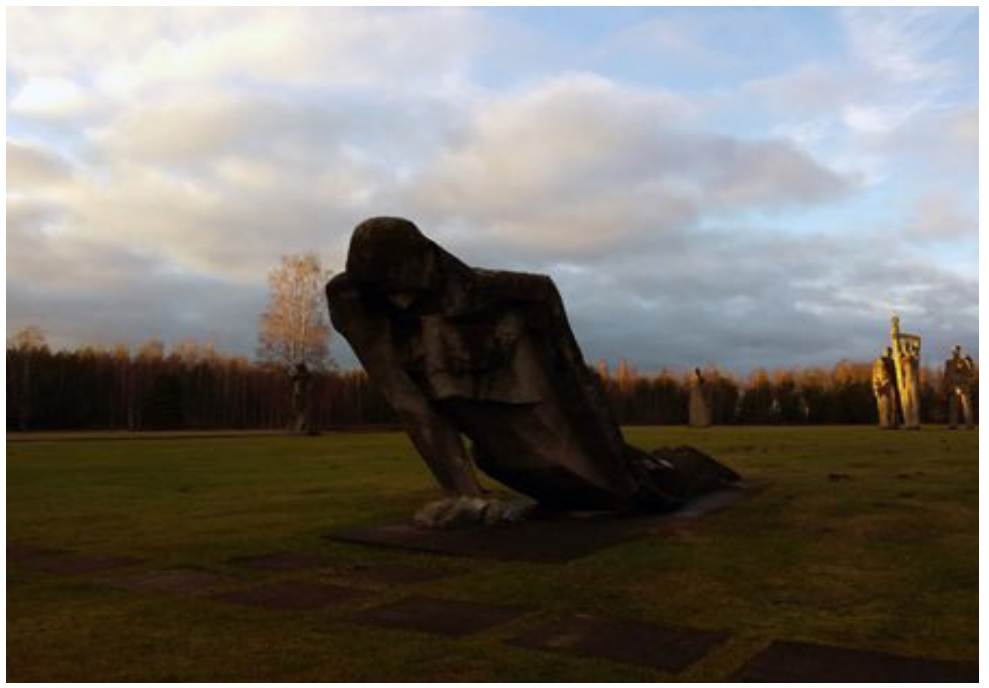

Figure 4. Salaspils Memorial Ensemble. Photo by Janis Konoshonoks. 
In 2004, thanks to a donation by Larry Pik, a former prisoner of the Salaspils camp, a monument to commemorate the foreign Jews who had died there was erected. The monument bears the Star of David and an inscription in Hebrew, Latvian and German: 'To honour the dead and as a warning to the living. In memory of the Jews deported from Germany, Austria and Czechia, who from December 1941 to June 1942 died from hunger, cold and inhumanity and have found eternal rest in the Salaspils forest'. In 2018, a new exhibition was unveiled, telling the history of this memorial site.

Despite its initial reference to solidarity, the Salaspils Memorial 'possesses a clear and well-considered emotional drama' (Gaber 2021). It is an example where history allows both past events to be returned to the present and the sculpture ensemble itself, thus creating deep emotions and strengthening this memorial as an impressive place of memory and commemoration.

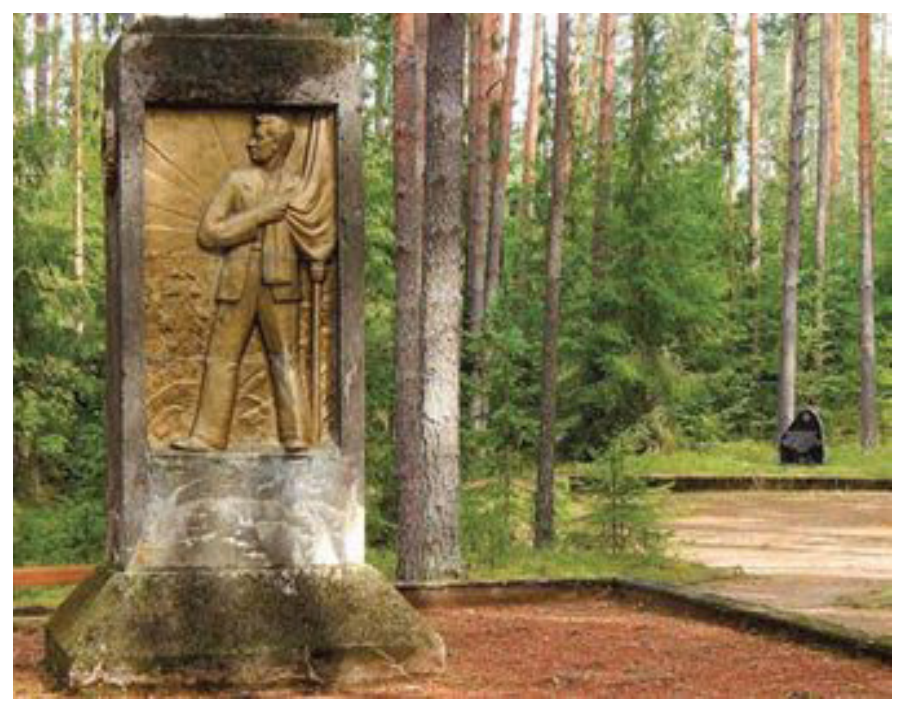

Figure 5. Memorial in Valka. Photo from the site Holocaust Memorial Places in Latvia. (c) 2021 Center for Judaic Studies at the University of Latvia. 
The symbol of social resistance was used in the memorial to the Nazi victims in Valka, in the area where the Jews of Valka and its vicinity were murdered in 1941. Despite the existence of documentary information telling what happened at this place, a monument was erected without any inscriptions. Thus, it can be said that the figure of a man depicted in the monument carried a misleading message about this place of death. The man, who is holding the flag in his hands, most likely in red, symbolizes respect for the comrades who were killed here in 1941, but this picture says nothing about the specific victims. Moreover, during the Soviet era, such monuments were seen in many parks, where this monument would probably fit more than in this place of Nazi crime.

The monument seems to have broken the trace between the past and the place where it was erected, so this place has ceased to be a place of memory. The significance of the historical text with which the memorial addresses us and creates a definite emotional experience became apparent only after the memorial's restoration. In 2008, the Council of Jewish Communities of Latvia erected a memorial stone with the six-pointed Star of David, a short text in Yiddish and the actual names of the murdered not far from the Soviet monument. Perhaps at least some visitors, learning from this epitaph that whole families were among those killed at this place, might change their attitudes towards this past event, so that it is no longer just a forgotten fact of history for them.

The erection of new Holocaust memorials started in the early 1990s. Nevertheless, the anonymity inherent in the Soviet era continued to exist in the first post-Soviet years as well. In 1993 a monument in the shape of a human skull (author Gvido Buls) was erected in the Smecere Pine Forest near Madona. About seven hundred residents of Madona and its vicinity had been killed there in one day, on 8 August 1941. Among the victims, 250 were Jews.

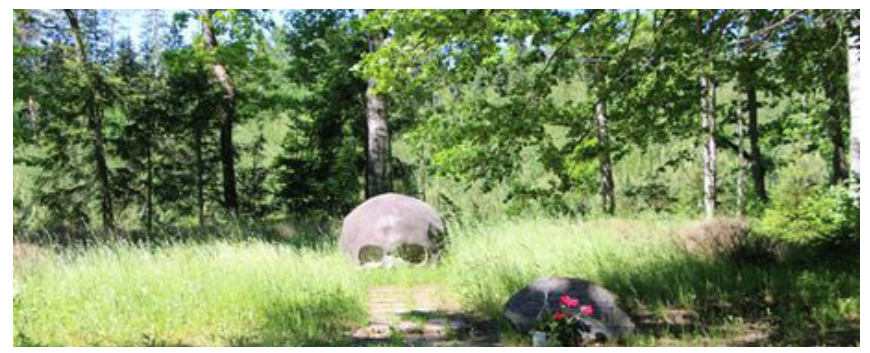

Figure 6. Memorial in the Smecere Pine Forest. Madona, summer of 2020. Photo by Georgijs Konkovs. 
This monument replaced the old one built in 1960, which has not been preserved. Gvido Buls successfully forms an imposing experiential space, its shape closely linked to the terrible events with which this place is associated with the memories of local people. From the older generation's stories, we know that some of those who were shot were buried alive, and that long after the massacre moans were heard of someone trying to get out of the grave.

However, this monument was initially erected without any inscriptions on or next to it. Only after more than ten years, in 2006, was a small stone placed next to it with an inscription in Latvian 'Memorial place of the residents of Madona and its vicinity, who were killed after the invasion by the Nazi German army'. Thus, the reference to the history of this place concretizes the past event. Still, it practically does not change anything in this site's impact on its visitors, even if they know nothing about what happened there. The monument created by Buls as a symbol of the presence of death only acquires an additional connection to a specific geographical location.

If we return to the analysis of the relations between the place of memory and the historical text in the message carried by a particular memorial, then in the case of the Smecere Pine Forest memorial, it is undoubtedly the place of memory in these relations that is dominant. Moreover, it has become a convincing historical testimony of the past massacre, making one feel the event's horrors emotionally. Paradoxically, this feeling is exacerbated by the memorial's merging with the surrounding landscape and an air of abandonment.

Several monuments in Riga have experienced a similar evolution of style and symbolic meaning. For example, Rumbula is one of the largest sites of mass murders of Jews in Europe. About 25,000 prisoners from the Riga ghetto and almost a thousand foreign Jews brought from Berlin, as well as Soviet prisoners of war, were killed in the Rumbula forest during two actions on 30 November and 8 December 1941. In 1944 another two hundred men from Kaiserwald concentration camp were killed in the same place. In 1964, a memorial stone with an inscription 'To the Victims of Fascism' in Latvian, Russian and Yiddish was erected. However, during the Soviet period, there were no other signs or information related to the Holocaust in Rumbula, even though 'Jewish community activists kept organising, throughout the almost fifty years of [the] postwar Soviet occupation of Latvia, clandestine weekly meetings on the site of collective killings in the Rumbula forest' (Zisere 2019: 302). 


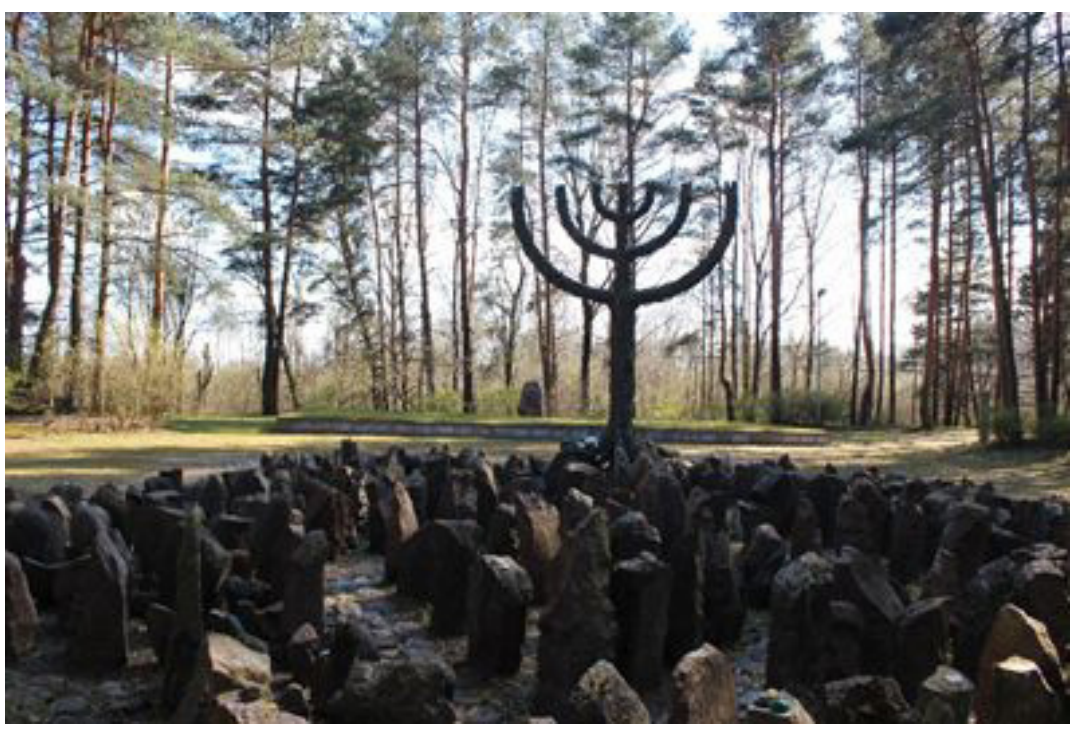

Figure 7. Memorial in the Rumbula forest. Summer of 2020. Photo by Diana Popova.

A memorial ensemble in the new style designed by the architect Sergey Rizh was unveiled in Rumbula in 2002. It was created with financial support from Latvia, Israel, the USA and Germany, as well as some private individuals. At the road leading to the memorial, a metal construction symbolizing the force of the Nazis has been installed. According to the architect Sergei Rizh, 'Metal symbolises the atrocity of Nazism - forces that destroyed everyone who did not fit into the Nazi view of the right' (Riga Monuments Agency 2021). The road leads to the memorial's central part, shaped like the Star of David with a menorah as 'a tree of life' above it. The menorah is surrounded by uncut stones of the sort that are traditional for a burial ground in Jewish culture. On them are engraved the names of slaughtered Jews. Several cobblestones are also present bearing the names of the streets in Riga's ghetto. The symbolism of uncut stones has several meanings, the best known -being that they symbolize the cemetery. According to Exodus 20:22, and some other places of the Bible, God prefers only uncut stones ('stones cut without hands'), making such stones fit for inclusion in the altar to the victims. 
Moreover, as 'living stones' the uncut stones symbolize God's innocent children, as well as shattered and destroyed lives in the context of past events in Rumbula. From here, cobblestones as artificial stones have a different meaning. They are signs of idolatry. An idol is a creation of man where he worships his own effort that leads him to evil and is not acceptable to God.

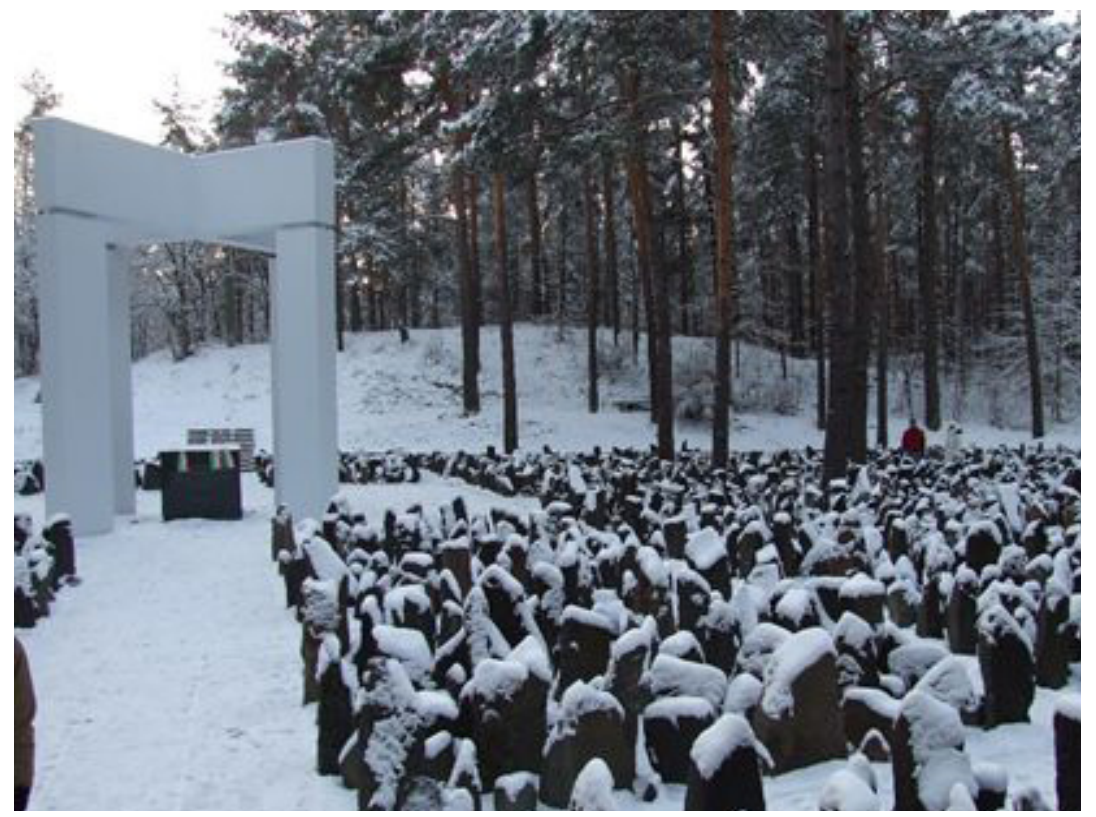

Figure 8. Memorial in the Bikernieki forest. Winter of 2019. Photo by Diana Popova.

A memorial in a similar style has also been erected in the Bikernieki forest. This memorial is dedicated to about 35,000 people who were killed in the Bikernieki forest during the Nazi occupation, 20,000 of them were Jews, including 1112,000 from other European countries. About 15,000 were Soviet prisoners of war. A memorial to the victims of Nazism of all nationalities, also created by Sergei Rizh, was unveiled in 2001. 
The paths through the 'forest' of the torn granite stones lead past stones with the names of European cities: Brno, Stuttgart, Paderborn, Kiel, Prague, Bremen, Hamburg, Dresden, and others. This indicates that victims of the Bikernieki massacre came from these places and that Jewish communities in these cities were destroyed during the Holocaust. In the middle of the stone forest rises a cross-arch based on four concrete pylons, beneath which is a black granite cube, an altar with an inscription from the Book of Job in several languages: 'O Earth, cover not my blood, and let my cry find no resting place!'

Forty concrete piles have been installed over this whole forest clearing to mark the gravesites. They depict a stylised crown of thorns, the years '19411944', and indications of the victims' affiliation: a crown for prisoners of war, a Star of David for the Jews and a cross for other civilians (Riga Monuments Agency 2021).

Both memorials in Rumbula and Biķernieki have been designed with deep involvement in the Jewish tradition, where history is the memory of this nation, the memory in which people disappear. Simultaneously, these memorials are places of a memory that is painful for everybody, and thus they also represent the universal drama. Perhaps the impression of these two memorials is in line with what LaCapra wrote: 'The memory site is generally also a site of trauma, and the extent to which it remains invested with trauma marks the extent to which memory has not been effective in coming to terms with it, notably through the fashion of mourning' (LaCapra 1998: 10).

Although the symbolism of the Rumbula and Bikernieki memorials contains many references to the Jewish religious tradition, there are also several memorials in Riga with a symbolic language that extends beyond the boundaries of any one religion. One such memorial commemorates the victims of the Jewish genocide at 25 Gogola Street, a place where on 4 July 1941, the Riga Great Choral Synagogue was burned down with many Jews inside it. In 1988, a memorial stone with a Star of David was placed there, and in 1993 a memorial was unveiled, also designed by Sergey Rizh.

This memorial consists of the synagogue's symbolic walls and some built-in original ornamental elements found during excavations. In 2007, a monument to Žanis Lipke and other Latvian saviours of Jews was erected next to the memorial. The monument consists of a high wall twelve metres long and six metres high, which is almost falling down, which supports columns with the names of 270 saviours of Jews inscribed on them. Žanis Lipke, who saved 56 people, is 
portrayed in the central column. In this urban setting, the memorial is a stark reminder of destruction and genocide ((Riga Monuments Agency 2021). The white wall, which seems to threaten to destroy all living things, also symbolizes destruction. In turn, the support columns symbolize possible salvation from death and the belief that good can be born amid evil, just as light is born in the deepest darkness.

The memorial on the site of the former Kaiserwald concentration camp has a similar symbolic message. Although at first this monument, situated next to heavy traffic, is difficult to grasp as a sign of the Holocaust, its symbolism addresses passers-by at first sight. Acquaintance with the history of this place that can be read at the foot of the monument makes it possible to understand the message of this place of memory even more deeply.

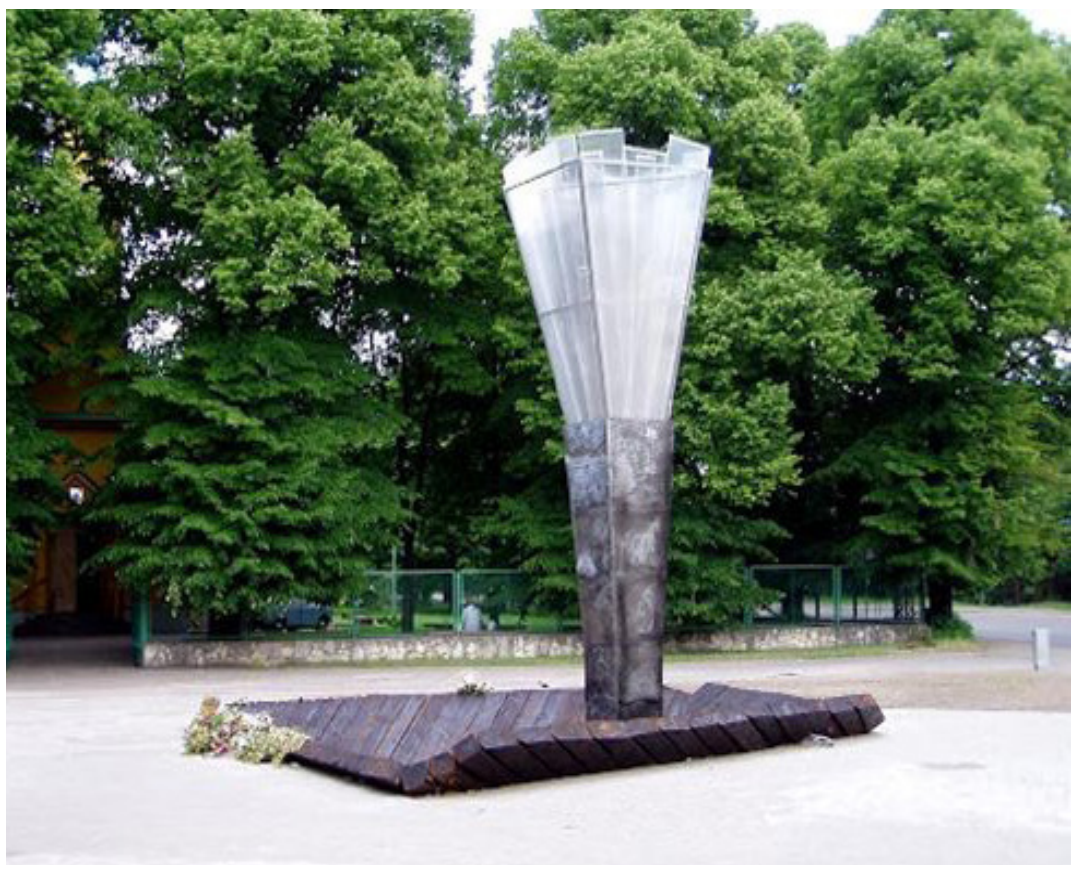

Figure 9. Kaiserwald concentration camp memorial. From the site: Holocaust Memorial Places in Latvia. ( 2021 Center for Judaic Studies at the University of Latvia. 
The monument is based on a cone made out of railway bearings. There is a single metal column in the centre that widens into a metal mesh in the form of a blossom at the top. The symbolic image of the central element has several explanations: it can be compared to a sprout growing in the middle of the bomb crater, to a torch (it is illuminated in the dark) or to a metaphorical representation of the tree of life. The symbolism of the contrasting materials, the metal and glass, 'allows to combine in one overall picture the references to the railway as an allegory of the road of torture, the resistance personified in metal and the human life equated to the fragility of glass' (Riga Monuments Agency 2021). Compared to other memorials, this memorial is characterized by a very high level of abstraction. Its symbolic language addresses the universal message about death that evokes its opposite - life and survival $\neg-$ to a broad and very diverse audience.

\section{Some conclusions}

The history of Holocaust memorials in Latvia is like the history of these memorials elsewhere in Europe: it reflects changes in post-war political culture and shows how similar and different is the reception of the events of the Holocaust by one or other of the post-war generations. From the examples considered here, it can be concluded that the development of Holocaust memorials in Vidzeme overall repeats the formation of similar genres elsewhere in Europe after the 1960s. True, we need to talk here about a delay in time influenced by the attitude of the Soviet regime towards the commemoration of Holocaust events.

Holocaust memorials have been erected in Vidzeme in places of massacres or where the victims of these killings have been buried. Simultaneously, it should be noted that these victims are anonymised. Moreover, as in the example of Valka, the monuments' symbolic language is used to convey a deliberately misleading message. In several cases, the memorials do not fully function as lieux de mémoire and have turned into merely historical sites, for which some elements of the general public have no interest.

As elsewhere in Europe, these examples show that Holocaust memorials are becoming more impressive and more abstract. New symbols, both religious and universal, are being introduced into their iconography. Of course, the Riga memorials are mainly meant here. From the late 1990s, memorials began to be designed chiefly as signposts for the future. 


\section{Acknowledgement}

This research is being funded by the Latvian Council of Science, under the project title of 'Difficult Heritage: Between the Memorisation and Contemporary Tourism Production and Consumption. The Case of Holocaust Sites in Latvia' (MemoTours), project No. lzp-2019/1-0241.

\section{References}

Bediḳe, Agnese 2000. Limbažu pilsētas ebreji 30. gadu beigās līdz 1944. gadam - laikabiedru atmiņās [The Jews of Limbaži in the late 1930s until 1944 - in the memories of contemporaries]. Available at https://www.lu.lv/jsc/pilsetas/vidzeme/limbazi/

Feinstein, Stephen C. 2005. Introduction. In: Feinstein, Stephen C. (ed.). A Scream/ A Repetition/ A Transformation. Absence/ Presence: Critical Essays on the Artistic Memory of the Holocaust. Syracuse, New York: Syracuse University Press, pp. xxi-xxxii.

Friedlander, Saul 1993. Reflections on Nazism: An Essay on Kitsch and Death. Bloomington: Indiana University Press

Gaber, Marc 2021. Salaspils Memorial, 1967. The Latvian Culture Canon. Available at https://kulturaskanons.lv/en/archive/salaspils-memorials/

Haynes, Stephen R. 1995. Jews and the Christian Imagination: Reluctant Witness. Louisville: Westminster/John Knox Press.

LaCapra, Dominick 1998. History and Memory after Auschwitz. Ithaca and London: Cornell University Press.

Lang, Berel 2000. Holocaust Representation: Art Within the Limits of History and Ethics. Baltimore: Johns Hopkins University Press.

Marcuse, Harold 2010. Holocaust Memorials: The Emergence of a Genre. American Historical Review, Vol. 115, Issue 1, 53-89.

Melers, Meijers 2013. Latvijas ebreju kopienas vēsture un holokausta pieminas vietas [History of the Latvian Jewish community and Holocaust memorial sites]. Riga: Institute of Philosophy and Sociology, University of Latvia.

Milton, Sybil 1991. In Fitting Memory: The Art and Politics of Holocaust Memorials [eBook]. Detroit, Michigan: Wayne State University Press. Available at https:// www.scribd.com/read/389549144/In-Fitting-Memory-The-Art-and-Politicsof-Holocaust-Memorials

Nora, Pierre 1974. Le retour de lévénement. Faire de l'histoire, J. Le Goff and P. Nora (éd.), vol. 1, Paris: Gallimard, pp. 210-227. 
Nora, Pierre 1997. Between Memory and History. In: Pierre Nora (ed.). The Realms of Memory: Rethinking the French Past. Vol. 1: Conflicts and Divisions. New York: Columbia University Press, pp. 1-20.

Ricoeur, Paul 2009. Memory, History, Forgetting [eBook]. Chicago: The University of Chicago Press, Available at https://www.perlego.com/book/1853274/memoryhistory-forgetting-pdf

Riga Monuments Agency 2021. Available at http://www.rigaspieminekli.lv/?lapa=piemineklis\&zanrs $=4 \&$ rajons $=4 \&$ id $=128$

Zisere, Bella 2019. The Transformation of Holocaust Memory in Post-Soviet Latvia. In: Himka, John-Paul and Michlic, Joanna Beata (eds.). Bringing the Dark Past to Light: The Reception of the Holocaust in Postcommunist Europe. UNP-Nebraska, pp. 300-318.

Solveiga Krumina-Konkova, Dr Phil., is a leading researcher at the Institute of Philosophy and Sociology of the University of Latvia and a corresponding member of the Latvian Academy of Sciences. Her research interests include the history of the Church-State relations in the Soviet times and the history and current development of religious-philosophical ideas in Latvia, mostly of Eastern religions. In recent years, she has also studied the history of Holocaust remembrance in Latvia. She is the editor-in-chief of the periodical Religiskifilozofiski raksti (Religious-Philosophical Articles). 
